DOI: $10.20472 / S S .2018 .7 .1 .004$

\title{
CHALLENGING THE MASCULINITY INDEX: THE END OF A CROSS-CULTURAL MYTH
}

\author{
JEROME DUMETZ, JAN CADIL
}

\begin{abstract}
:
This article aims to review the coherence of the definition of the Masculinity Index, one of the most cited dimensions in cross-cultural management. The study challenges the claims supporting the design, the definition and ultimately the validity of the Masculinity Index that are the basis of it applications in management theory and practice.
\end{abstract}

The paper is based on the empirical analysis of the MAS index utilizing a standard quantitative approach. The authors ran cross-section regressions with control variables for the applications of the index that could be quantified: According to Hofstede, high MAS Index countries have relatively higher defence spending, a relatively lower aid spending on poor countries, less gender equality at work and have higher share of women teaching small children and a lower share of women teaching at universities.

The analysis did not validate those claims and therefore the hypothesis of the Masculinity index. The authors provide empirical proof of the lack of validity of the MAS index to compare national cultures, recommend abandoning the MAS index and instead using alternative instruments of gender equalitarianism.

\section{Keywords:}

Intercultural management, Cross-cultural management, Intercultural model, Masculinity/Femininity Index, Gender Equalitarianism

JEL Classification: M14, 057, Z10

\section{Authors:}

JEROME DUMETZ, Plekhanov Russian Economic University, Russian Federation, Email: jerome@clamart.net

JAN CADIL, Unicorn College, Czech Republic, Email: jan.cadil@unicorncollege.cz

\section{Citation:}

JEROME DUMETZ, JAN CADIL (2018). Challenging the Masculinity index: The end of a cross-cultural myth. International Journal of Social Sciences, Vol. VII(1), pp. 49-68., 10.20472/SS.2018.7.1.004 


\section{Introduction}

The cultural background of organisations' stakeholders - managers and employees alike - is increasingly influencing contemporary management due to the accelerating globalization of the business environment (migration, multinational companies). Following early $20^{\text {th }}$ century concepts of scientific management (Taylor, 1911; Fayol, 1918), many tried to isolate some universal characteristics of management, to be replicated worldwide. However, as the exchange of goods and people intensified, these attempts were found to be meaningless. Too many cultural differences were involved for management to apply universal rules.

In 1980, Geert Hofstede from the Netherlands was probably the first researcher to clearly and openly present the connection between culture and management using the data of employees' surveys conducted by IBM in 1968 and 1972 (Hofstede, 1980). His research became instantly renowned; widely used by scholars and one of the most cited works of cross-cultural management today (Baskerville, 2002, Hofstede, 2001). Hofstede defined four basic dimensions that shape the cultural background of nations and individuals, and described behavioural patterns based on such cultural profiles (see direct quotations in Appendix).

Out of those four dimensions, the Masculinity/Femininity index (MAS Index hereafter) is clearly Hofstede's own contribution as the others may easily be traced to many previous academic researches (see details in following section).

Along with the other dimensions, the MAS index was subsequently implemented into strategic management theories and incorporated into many studies and management publications. Generally, from a management point of view, Hofstede's original hypothesis is that masculine environments stress the assertiveness of the person and feminine environments focus more on care, attention and social surroundings. It can be concluded that masculine cultures are better motivated by higher earnings, career and individual success while feminine ones tend to foster a more consensus-oriented style of management, favour friendly atmosphere and employment security (Ahlstrom, Bruton 2009).

To give a concrete example - Pheng and Yuquan (2002) concluded that because China is ranked as more masculine than Singapore, organisations should adapt their management to cultural differences. As surprising as it may sound, they recommended maintaining a higher job stress environment, and to focus more on individual achievements for Chinese employees. In Singapore, the advice was to lower the stress at work, and to focus on group integration.

Although many researchers in the field of management and business treat the MAS index as a useful explanatory variable, they use it without doubting its intrinsic validity (for 
example Kotha, 2006; Browaeys, 2008; Mead, 2009; Morschett, 2010; Myasoedov, 2012; Shao, 2012). Critical voices can be heard as well (Holden, 2001; Dumetz, 2012), however, the criticism focuses mostly on the methodological or theoretical aspects of the MAS index (see the details below).

Since its introduction in the 80's, Hofstede's dimensions have been challenged for methodological shortcomings (Dorfman, 1988, Jones 2007), for the geographical bias of the sample analysed (Sondergaard, 1994) or for the paternity of the concept (HampdenTurner and Trompenaars, 1997), but, quite surprisingly, the original validity of the MAS index has rarely been tested empirically. Recently, however, some questions begin to be asked about the practical validity of the model (McSweeney, 2016; Minkov, 2017). Also, many comparisons between the original statistical findings and other independent analysis have been conducted (Yeh, 1988; Spector, 2001), however, the early statement linking national cultures characteristics and some supposed influences from genderinspired values has not been questioned. In other words, Hofstede's claim that MAS is "not meant to describe individuals, but dominant patterns of socialization ("mental programming") in nations" has never been challenged after more than three decades of massive use among lecturers and researchers. This is surprising.

In view of the overlooked position the MAS index has acquired in current cross-cultural academic and managerial literature, a thorough study was needed to confirm whether a higher MAS index really leads to higher focus on assertiveness (and other claims) before we use it and link it to management theories and practices.

The purpose of this paper is simple - to perform a statistical test of Hofstede's hypothesis between the MAS Index and the proposed cultural behaviours by analysing their correlation, and to prove or deny its validity.

\section{MAS Index definition and common critiques}

In his original research Hofstede analysed the questionnaires in terms of 4 'cultural dimensions' as mentioned above ${ }^{1}$. Those dimensions, bi-polar continuums derived from factor analysis, were:

- PDI Index: Power distance (large versus small)

- IDV Index: Individualism versus Collectivism

- MAS Index: Masculinity versus Femininity

- UAI Index: Uncertainty Avoidance (strong versus weak)

\footnotetext{
${ }^{1}$ Hofstede has introduced two more dimensions later on, time-orientation and indulgence, but this does not have any impact upon the MAS index.
} 
Several other dimensions have been added in following works (Minkov, 2010), but the original four can be considered the basis of his theory.

While the concept of masculinity-femininity goes back to the 30's (Terman \& Miles, 1936) the idea of applying such concept to entire national cultures is clearly Hofstede's own contribution as all the other three dimensions can be traced to other researchers. In 1961, F. Kluckhohn and F. Strodtbeck's Values Orientation Theory (Kluckhohn and Strodtbeck, 1961) proposed six dimensions to study culture. One of them, Social Relations (Hierarchical, Collateral or Individual) is similar to the PDI and IDV indices. McClelland's Need Theory (McClelland, 1961) cited by Hofstede, or T. Adorno's F-Scale (Adorno, 1950) are both concepts linked to Hierarchy, equivalent to Power Distance. The term Uncertainty Avoidance is borrowed from Cyert \& March (1963) analysing American organizations

Also, the Shame/Guilt approach by renowned anthropologist R. Benedict (Benedict, 1946) can be linked to the dimension of Individualism/Collectivism in its relationship between the group (Shame) and the individual (Guilt). While Hofstede favours the work of sociologists such as Inkele over that of anthropologists, nevertheless many of their works can be traced to modern cross-cultural management studies.

A peculiarity of the MAS index lays in the fact that country scores have not changed over time. Through the various published editions, while the definition of the index has evolved, the statistical results remain the same (Hofstede 1984, 1991 and 2001. See the appendix for precise quotes). The evolution of the index definition clearly shows a desire to transform the index, from what appears as a series of stereotyped and assumed values about men and women, into a more politically correct, business-related dimension, closer to the GLOBE's Gender Egalitarianism which measures "the degree to which a collective minimizes gender inequality" (House, 2004),

Since the mid 90's, Hofstede's work, including the MAS index, has received considerable criticism that he defended vigorously. The model was criticized for several reasons:

- The usage of nationalities as a proxy for culture was criticized (McSweeney, 2002) but, as Hofstede responded, it is quite difficult to distinguish between culture and nation as we usually lack relevant data (Hofstede, 2002). An even stronger criticism was related to the statistical properties of the research (there were originally only 40 countries) and its geographic coverage (Sondergaard, 1994): mostly North American, Western European and a few Asian countries.

- Others highlighted methodological limits linked to the questionnaires, such as the use of the same questions for several dimensions of the model (Dorfman, 1988). The use of logarithms in order to spread the concentrations of answers, hence exaggerating real differences between cultures, was also denounced (Gerhart, 2005). 
- That the research database was out of date is a frequent comment (Jones, 2007). Even today, Hofstede relies on statistics based upon questionnaires answered in 1968 and 1972. Also, throughout his published editions, the MAS index results remain the same, based upon the assumption that cultural traits do not evolve significantly. For instance, Japan's MAS index consistently scores 95 while Sweden has consistently scored 5, since the 1980 edition.

- Other critics focused on the supposed paternity of the dimensions used. In a notorious quarrel between Hofstede (Hofstede, 1996) and Trompenaars, the latter explained the similarity of some of his dimensions with those of his Dutch compatriot by the fact that they were created by other academics, before being introduced in Culture's Consequences (Hampden-Turner and Trompenaars, 1997).

- Also, some challenge the status of the observer outside the culture (Baskerville, 2002), doubting the neutrality of the model design. Ironically, this bias is called the Uncertainty Principle, also called the Heisenberg Principle, but has no link to the term Uncertainty Avoidance in cross-cultural management.

- Finally, Hofstede's original work invited criticisms of the terminology of his dimensions, in particular IDV and PDI (Smith, 1996).

It is obvious from this list that the criticism is mostly theoretical and academic. Many consider Hofstede's contribution on culture as the most widely cited in the world (Bond 2002; Hofstede 1997). However, few have asked and answered the simple question: Does the concept upon which the MAS index is built, actually work?

Inspired from the work of Hoppe and Merritt, who previously pointed at the "limitations in the generalizability of the MAS index" (Hoppe 1998, Merritt 2000), Emrich, Denmark and DenHartog (2004) are probably the ones who went as close as it gets to question the intrinsic validity of the MAS index. They did so as they were working on Gender Equalitarianism for the GLOBE project. Although Emrich, Denmark and DenHartog acknowledge that ordering cultures on a continuum based on the gender equality is a useful cultural dimension, they postulate that the MAS index covers in reality four dimensions of societal culture. These four dimensions are: Assertiveness, Gender Equalitarianism, Humane Orientation and Achievement Orientation. They concluded "it is very difficult to interpret the masculinity/femininity measure itself and its correlations with other measures". They created an index, Gender Equalitarianism which, "reflects societies' beliefs about whether members' biological sex should determine the roles that they play in their homes, business organizations and communities" (Emrich, 2004).

We believe the roots of the many criticisms of Hofstede's MAS index lie in the genesis of the index. The MAS index is presented as an empirically obtained variable, which leads to inflexible statements about human behaviour. Yet, those statements are purely 
hypothetical. The easiest way to prove or deny its validity (either the validity of the index or the validity of related hypothetical behaviour patterns) is to correlate one against the other. This approach is simple to perform on a limited scale but it is not without difficulties and pitfalls.

Only a limited number of hypothesised behaviour patterns can be analysed; many are too abstract to be measured such as the following claims:

- low MAS countries should favour welfare societies (Hofstede, 1991).

- Children are supposed to be "controlled by obedience in high MAS cultures", Vs. controlled by the examples set by parents

- $\quad$ in more feminine cultures average students are supposed to be norm (Vs. the best students in masculine ones);

- $\quad$ "failure in school is a disaster in a high MAS country while being a relatively minor incident in low MAS countries"

- low MAS societies are supposed to favour resolving conflicts by compromise and negotiation, whereas in high MAS countries "there is a feeling that conflicts should be resolved by a good fight".

Finally, some undocumented claims of Hofstede in the 80's emerge as out of sync in 2017, such as "Scientists, engineers, technicians (...) call for Masculine values".

However, it can be assumed that if several relations are found to be statistically significant, the MAS index is indeed likely to impact human behaviour (and vice versa). The MAS index is justified throughout the publications with the help of many claims that are not quantifiable, but also not challenged. This is mostly due to the approximate validity of two extreme examples (usually USA for high MAS, and the country of origin of the author, the Netherlands for low MAS) that should not suffice to validate neither the entire list of countries, nor the dimension itself. Often, without the abundant illustrations displaying the Dutch and US cultures, the case for MAS index appears very weak.

The authors of this paper believe a statistical comparison between the quantifiable claims and existing databases of primary data would shed a definite light on the challenged dimension and present supporting or refuting arguments.

\section{Data and Method}

From a statistical point of view, the authors recognize the necessity to control other factors that can possibly impact the MAS index and cause distorted results. For example, different socio-economic or institutional conditions may strongly influence the data and blur the MAS index validity.

We challenged the MAS index values with statements extracted directly from the book 
Cultures and Organizations (Hofstede 1991, 1984). When it was possible, we used the MAS index data published in 2001. However, as previously mentioned, the MAS index did not change since the first publication of 1980. Consequently, data from any period could be used without any loss of statistical validity. Generally we used longer-term average values of all indicators to focus on long-term relationship rather than shot-term deviations. 64 countries were included into the basic sample with their MAS values.

We used cross-section regression analysis utilizing common Ordinary Least Squares (OLS) method with control variables, when the output variable reflects some of the MAS index-based behaviour patterns that we found quantifiable. The general equation we estimate is

$$
y_{i j}=b_{0}+b_{1} m_{i}+\sum_{n=1} c_{n} x_{n}+\varepsilon_{i}
$$

where $y$ is respective output $j$ which is tested, mas is the value of MAS index and $x$ are control variables. We tested the following hypotheses with the respective output variables:

1. High MAS index countries have relatively higher Defence spending. Selected output variable: share of defence spending on GDP - def. Data were collected from World Bank database, average values from period 2003-2013. 63 observations out of 64 were included.

2. High MAS index countries have a relatively lower aid spending on poor countries. Selected output variable: share of aid on GDP - aid. OECD database was used, average values for period 2008-2013. As the group of aiding countries is quite limited - 34 out of 64 have the data available.

3. High MAS index countries have less gender equality. More output variables were selected to deal with this hypothesis. Output variable 1: Gender inequality index gii. 59 countries had the gii available. Output variable 2: women's share of legislators, senior officials and managers -wmo. 53 countries had the data available for this indicator. Output variable 3: gender pay gap as a relative share of women's medium monthly earnings to men's medium monthly earnings - gpg. Data were available only for 29 out of 64 countries concerning this indicator. All variables were collected from United Nations database. For gipg the average value in period 2000-2012 was used, for wmo the average value in period 2003-2013 and for gii the average value in period 2000-2012.

4. High MAS index countries have higher share of women teaching small children and a lower share of women teaching at universities. Data were collected from OECD database for the year 2015.

Regarding the dependent variable - MAS index, we use two forms of it. We use the MAS 
as an index itself (having values of 5-110) and we also use the ranking (order) of MAS among the countries (having values of 1-64). We choose these two forms as the distance in MAS varies substantially between countries ordered by ranking. While the distance between $1^{\text {st }}$ and second least masculine countries (Sweden and Norway) is 3, the distance between $2^{\text {nd }}$ and $3^{\text {rd }}$ (Denmark) is 8 points. We believe that it is reasonable to analyse both - the MAS index value and the ranking.

We selected three independent factors (as control variables) that could possibly affect the dependent variable, besides the MAS. The first control variable is the United Nations' Human Development index - hdi, which is a more complex indicator than the usual GDP per capita and covers also education and quality of life. It can be reasonably assumed that countries with higher HDI will tend to spend more on foreign aid for example and will have similar socio-economic background. An average index value for the period 20002013 was used; data were collected from the UN database. The second control variable is a dummy $(0,1)$ variable of the countries' involvement in military conflict since WW2 con. It can be assumed that countries involved, even involuntarily or on basis of membership in organizations like NATO, in military conflict will spend more on defence. This variable was obtained from the Uppsala Conflict Data Program (UCDP). As a third control variable, we selected the countries' dominant religion, which could possibly influence all the output We distinguish among three possible cases - dominant Christian - dch, dominant other (mostly Islam in our panel) - dot and not dominant religion in country - nod. Although we are aware of the possible oversimplification of such situation, the limited number of observations does not allow us to perform any detailed stratification. Moreover, doing this would not yield reasonable results, as some dominant religions are present only in one observation (like Judaism or Buddhism). The CIA World Factbook was used as data source for this set of dummies. All control variables data were available for all countries in the base sample, i.e. 64 , so adding them did not reduce the sample at all. Table 1 summarizes all variables. 
Table 1 : Descriptive statistics - summary

\begin{tabular}{|l|r|r|r|r|r|}
\hline Variable & \multicolumn{1}{l|}{ Obs } & \multicolumn{1}{l|}{ Mean } & \multicolumn{1}{l|}{ Std. Dev. } & \multicolumn{1}{l|}{ Min } \\
\hline & & & \multicolumn{3}{l|}{ Max } \\
\hline MAS & 64,00 & 50,19 & 19,59 & 5,00 & 110,00 \\
\hline def & 63,00 & 1,78 & 1,13 & 0,46 & 7,19 \\
\hline aid & 30,00 & 0,00 & 0,00 & 0,00 & 0,02 \\
\hline gii & 59,00 & 0,26 & 0,16 & 0,05 & 0,61 \\
\hline wmo & 53,00 & 30,21 & 9,29 & 2,97 & 54,82 \\
\hline gpg & 29,00 & 23,16 & 8,58 & 7,05 & 42,50 \\
\hline hdi & 64,00 & 0,78 & 0,11 & 0,52 & 0,94 \\
\hline con & 64,00 & 0,70 & 0,46 & 0,00 & 1,00 \\
\hline dch & 64,00 & 0,52 & 0,50 & 0,00 & 1,00 \\
\hline dot & 64,00 & 0,17 & 0,38 & 0,00 & 1,00 \\
\hline nod & 64,00 & 0,31 & 0,47 & 0,00 & 1,00 \\
\hline fped & 35,00 & 81,79 & 10,65 & 49,50 & 98,80 \\
\hline fted & 31,00 & 43,54 & 7,60 & 25,21 & 61,00 \\
\hline
\end{tabular}

Estimates of (1) were performed by using standard OLS at first place. However, tests in residuals have often shown a problem of heteroskedasticity (Breusch-Pagan / CookWeisberg test was used). Therefore, we opted for linear regression using robust estimate of variance option in these cases. Moreover, we tested for influence factors (outliers) using Cook'd D test, which did not reveal any significant outliers in all estimates. 


\section{Results}

Tables 2 and 3 summarize all results

Table 2: Summary of hypothesis using MAS values

\begin{tabular}{|c|c|c|c|c|c|c|c|}
\hline dependent variable & & & & predictors & & & $\mathrm{R} 2$ \\
\hline & HDI & MAS value & conflict & dominant christian & dominant others & constant & \\
\hline defence spending & $\begin{array}{r}0,885 \\
(2,642) \\
\end{array}$ & $-0,005(0,006)$ & $\begin{array}{l}0,198 \\
(0,354) \\
\end{array}$ & $\begin{array}{l}-0,189 \\
(0,265) \\
\end{array}$ & $\begin{array}{l}0,961 \\
(0,872) \\
\end{array}$ & $\begin{array}{l}1,151 \\
(2,059) \\
\end{array}$ & 0,14 \\
\hline aid & $\begin{array}{l}0,046^{*} \\
(0,025)\end{array}$ & $\begin{array}{l}-0,00007^{\star *} \\
(0,00002)\end{array}$ & omitted & $\begin{array}{l}0,001 \\
(0,001)\end{array}$ & $\begin{array}{l}0,0006 \\
(0,002) \\
\end{array}$ & $\begin{array}{l}-0,032 \\
(0,022) \\
\end{array}$ & 0,58 \\
\hline gender equality & $\begin{array}{l}-1,342^{\star \star \star} \\
(0,092)\end{array}$ & $\begin{array}{l}0,0003 \\
(0,0004) \\
\end{array}$ & \begin{tabular}{|l}
$-0,048^{*}$ \\
$(0,025)$ \\
\end{tabular} & $\begin{array}{l}0,010 \\
(0,023) \\
\end{array}$ & $\begin{array}{l}-0,009 \\
(0,030) \\
\end{array}$ & $\begin{array}{l}1,329^{\star \star *} \\
(0,080) \\
\end{array}$ & 0,83 \\
\hline share of women in top positions & $\begin{array}{l}24,52 \\
(16,47) \\
\end{array}$ & $\begin{array}{l}0,052 \\
(0,047) \\
\end{array}$ & $\begin{array}{l}-4,529 \\
(3,097) \\
\end{array}$ & $\begin{array}{l}-1,097 \\
(2,576) \\
\end{array}$ & $\begin{array}{l}-11,291^{\star \star \star} \\
(4,228) \\
\end{array}$ & $\begin{array}{l}14,103 \\
(14,240) \\
\end{array}$ & 0,42 \\
\hline gender pay gap & \begin{tabular}{|l|}
30,017 \\
$(42,669)$
\end{tabular} & $\begin{array}{l}0,051 \\
(0,104) \\
\end{array}$ & $\begin{array}{l}4,857 \\
(3,532) \\
\end{array}$ & $\begin{array}{l}-6,173 \\
(4,644) \\
\end{array}$ & $\begin{array}{l}8,828^{\star \star} \\
(4,260)\end{array}$ & \begin{tabular}{|l|}
$-5,949$ \\
$(36,915)$ \\
\end{tabular} & 0,29 \\
\hline share of women in primary education & $\begin{array}{l}23,79 \\
(28,37) \\
\end{array}$ & $\begin{array}{l}0,054 \\
(0,057) \\
\end{array}$ & $\begin{array}{l}1,09 \\
(7,15)\end{array}$ & \begin{tabular}{|l|}
$-3,80$ \\
$(3,32)$ \\
\end{tabular} & $\begin{array}{l}-19,27^{\star *} \\
(8,37)\end{array}$ & $\begin{array}{l}62,42^{\star \star \star} \\
(22,83) \\
\end{array}$ & 0,41 \\
\hline share of women in tertiary education & $\begin{array}{l}-73,44^{* \star \star} \\
(16,89)\end{array}$ & $\begin{array}{l}-0,076^{\star *} \\
(0,029)\end{array}$ & $\begin{array}{l}19,93^{* *} \\
(8,65)\end{array}$ & $\begin{array}{l}1,66 \\
(2,42)\end{array}$ & $\begin{array}{l}-10,13^{* * *} \\
(2,82)\end{array}$ & $\begin{array}{l}90,60^{* * *} \\
(14,96)\end{array}$ & 0,46 \\
\hline
\end{tabular}

Note: The ${ }^{* * *}$ and ${ }^{* * *}$ indicate the $90 \%$ level of significance $(p<0,1), 95 \%$ level of significance $(p<0,05)$

and $99 \%$ level of significance $(p<0,01)$

Table 3: Summary of hypothesis using MAS ranking

\begin{tabular}{|c|c|c|c|c|c|c|c|}
\hline dependent variable & & & & predictors & & & $\mathrm{R} 2$ \\
\hline & HDI & MAS rank & conflict & dominant christian & dominant others & constant & \\
\hline & & & & & & & \\
\hline defence spending & $\begin{array}{r}0,920 \\
(2,634) \\
\end{array}$ & $-0,006(0,006)$ & $\begin{array}{l}0,195 \\
(0,355) \\
\end{array}$ & \begin{tabular}{|l|}
$-0,185$ \\
$(0,263)$ \\
\end{tabular} & \begin{tabular}{|l|}
0,957 \\
$(0,871)$ \\
\end{tabular} & \begin{tabular}{|l|}
1,046 \\
$(2,002)$ \\
\end{tabular} & 0,14 \\
\hline aid & $\begin{array}{l}0,050^{*} \\
(0,026)\end{array}$ & $\begin{array}{l}-0,00007^{\star *} \\
(0,00002)\end{array}$ & omitted & $\begin{array}{l}0,001 \\
(0,001)\end{array}$ & $\begin{array}{l}0,0003 \\
(0,003)\end{array}$ & $\begin{array}{l}-0,037 \\
(0,023)\end{array}$ & 0,55 \\
\hline gender equality & $\begin{array}{l}-1,344^{\star \star \star} \\
(0,093)\end{array}$ & $\begin{array}{l}0,0002 \\
(0,0004)\end{array}$ & $\begin{array}{l}-0,048^{*} \\
(0,025)\end{array}$ & $\begin{array}{l}0,010 \\
(0,023)\end{array}$ & $\begin{array}{l}-0,009 \\
(0,030)\end{array}$ & $\begin{array}{l}1,338^{\star \star \star} \\
(0,080)\end{array}$ & 0,83 \\
\hline share of women in top positions & $\begin{array}{l}23,521 \\
(16,515)\end{array}$ & $\begin{array}{l}0,039 \\
(0,052)\end{array}$ & $\begin{array}{l}-4,502 \\
(3,105)\end{array}$ & $\begin{array}{l}-1,253 \\
(2,566)\end{array}$ & $\begin{array}{l}-11,470^{\star \star *} \\
(4,212)\end{array}$ & $\begin{array}{l}16,262 \\
(13,964)\end{array}$ & 0,42 \\
\hline gender pay gap & $\begin{array}{l}26,192 \\
(42,058)\end{array}$ & $\begin{array}{l}0,0410 \\
(0,103)\end{array}$ & $\begin{array}{l}4,904 \\
(5,709)\end{array}$ & $\begin{array}{l}-6,323 \\
(4,473)\end{array}$ & $\begin{array}{l}8,921^{\star *} \\
(4,055)\end{array}$ & $\begin{array}{l}-1,468 \\
(35,073)\end{array}$ & 0,28 \\
\hline share of women in primary education & $\begin{array}{l}22,89 \\
(28,46) \\
\end{array}$ & $\begin{array}{l}0,030 \\
(0,071) \\
\end{array}$ & $\begin{array}{l}1,34 \\
(7,02) \\
\end{array}$ & $\begin{array}{l}-3,87 \\
(3,38) \\
\end{array}$ & $\begin{array}{l}-19,04^{\star *} \\
(8,16)\end{array}$ & $\begin{array}{l}64,76^{\star \star *} \\
(22,80)\end{array}$ & 0,39 \\
\hline share of women in tertiary education & $\begin{array}{l}-73,44^{\star \star \star} \\
(16,89)\end{array}$ & $\begin{array}{l}-0,083^{\star \star} \\
(0,04)\end{array}$ & $\begin{array}{l}19,41^{\text {** }} \\
(8,48)\end{array}$ & $\begin{array}{l}1,63 \\
(2,41)\end{array}$ & $\begin{array}{l}-10,48^{\star \star \star} \\
(3,11)\end{array}$ & $\begin{array}{l}87,98^{* * *} \\
(15,04)\end{array}$ & 0,46 \\
\hline
\end{tabular}

Note: The ${ }^{*},{ }^{* *}$ and ${ }^{* * *}$ indicate the $90 \%$ level of significance $(p<0,1), 95 \%$ level of significance $(p<0,05)$ and $99 \%$ level of significance $(p<0,01)$

\subsection{Hypothesis $n^{\circ} 1$ - High MAS index countries have higher Defence spending}

"Defence spending as a percentage of GNP is positively correlated with masculinity." (1991 p.101). Clearly, the MAS index model does not work well in this case. With MAS tstatistics (but also F-test) far below its critical level. We can not find any statistically significant link between defence spending and MAS index so the hypothesis should be denied. Although, in theory, defence spending could be related to masculinity, the data analysis shows it is definitely not the case. 


\subsection{Hypothesis $n^{\circ} 2$ - High MAS index countries have lower aid spending}

"The only explanation of a high aid quote is a feminine national value system: the statistical correlation between aid in percentage of GNP and a country's masculinity index score is strongly negative (high index, low aid quote)." (1991 p. 99-100)

For the case of international aid the model works quite well. We can see statistically significant negative relation between MAS and aid which is in line with the hypothesis. Also the $\mathrm{R} 2$ is reasonably high. It can be concluded that the more a country is feminine (lower MAS) the more it spends on aid in percentage of GNP. We can also see positive dependency between aid and HDI.

\subsection{Hypothesis $n^{\circ} 3$ - High MAS index countries have less gender equality}

"One would expect that in countries with a more feminine culture more women would be elected to political office and occupy government posts. (1991 p. 101)

Also (quoting Maurice et. al, 1984, p.204) "wage differentials between men and women are smaller in (lower MAS) France than in Germany"

The third hypothesis is tested with the use of three estimates, although we recognise the UNPD's gii as a probably better indicator to cover whole gender inequality situation of a country - it is greatly influenced by the other two variables: The Gll, the gender pay gap and the share of women in senior officials, legislators and managers The reason is simple: While Hofstede naturally does not tell anything about the gii which was created in 2010, he is quite specific about the pay gap and the occupation of high positions by women. So, in order to limit the risks of "cherry picking", we chose to challenge the MAS index with all three variables.

It is quite obvious the MAS index can not relate to gender inequality in any of the three selected cases. For the case of gii, the driving force appears to be the HDI - the higher the HDI ranking, the higher the gender equality. Thus, the MAS index is statistically insignificant. Regarding the share of women in leading positions the situation is similar. Although the MAS index is again of no significance. It appears women are less likely to get a leading position in countries with non-Christian dominant religion, HDI is less statistically significant here but we may assume it has strong influence as well. The same can be stated regarding the gender pay gap - again, the MAS index has no effect (but women face greater inequality of earnings in countries with non-Christian dominant religion - mostly Islam in our sample).

The result of this hypothesis bears considerable significance because many cross-cultural specialists came to associate Hofstede's MAS index with gender equality (Chevrier, 2003; House, 2004). While the theory of having "feminine" societies tending to display gender equality values is appealing, it is not supported by facts. 


\subsection{Hypothesis $n^{\circ} 4-$ High MAS index countries have higher share of women teaching small children and a lower share of women teaching at universities.}

"In masculine societies women mainly teach younger children and men teach at universities." (1991 p. 91)

This hypothesis is essential because the MAS index is easily associated with the gender roles displayed in education. This assertion once again appeared coherent when using the typical extreme examples of the Netherlands or the USA like Hoftsede frequently does. It is indeed tempting to believe that feminine societies have more mixed gender roles (quote) hence accepting more easily men in primary education and women as University professors.

However, our analysis found that higher MAS does not mean higher share of women in primary education. At University level, it seems that higher MAS (higher MAS rank too) means lower share of women (higher share of men) at universities. But the value is quite low $-0,08$. That means that one rank (or MAS point as well) yields change of $0,8 \%$ in share of women at universities. We believe this variation is too weak to support such bold statement.

\section{Conclusion/discussion}

With his innovative 1980s work using questionnaires completed by IBM employees in 1968 and 1972, Geert Hofstede has rightly earned the honour of being considered one of the founders of cross-cultural management studies.

His model of cultural analysis using four dimensions has become a classic and the source of many publications. Despite a number of solid criticisms about various aspects of his concept, the validity of the dimensions themselves has not been challenged. The focus of most critics of Hofstede's model has been on analysing the statistical validity of the results of the countries' ranking per dimension. Such focus on the end result has actually over-shadowed the necessary analysis of the validity of the dimensions themselves.

Out of the four dimensions present in his work, the Masculinity/Femininity index (MAS Index) can be the most associated with Hofstede who transposed the social concept of gender values into a cultural set of values that could be applied to entire countries. In the last two decades, this dimension has become a common source of research in social, management and cultural studies. The authors of this study decided to concentrate on this dimension because many of the claims supporting the MAS index seemed unrealistic. Because this innovative work brought a convenient tool to lecturers, academics and managers interested in cross-cultural questions, most have concentrate their efforts on 
verifying the validity of the statistical findings. Publications after publications, the MAS index has been cited by professionals who eventually challenged the methodology of the analysis, but never questioned the theoretical backing of the dimension presented.

The very concept of the MAS index as a cultural dimension applicable to national cultures is actually proven wrong as a result of statistical estimations we have performed over various elements used by Hofstede to structure it. He provides many examples to support the validity of his dimension, but only a few can be related to quantitative data. We selected four of his claims about the consequences or applications of the MAS index: Defence spending, aid to poor countries, gender equality and gender roles in education. In order to test the validity of the MAS index, we applied a linear model with several control variables. We used cross section data of long-term averages to focus on long-term relations rather than short-term deviations. The results we yielded are quite straightforward and lead to the denial of the MAS index as a valid explanatory variable for selected hypotheses. The only hypothesis which was proven correct was about aid the more feminine the country is (lower MAS) the higher is its aid assistance. All the other hypotheses were proven wrong, which gives reasonable basis to discounting Hofstede's hypothesis supporting the MAS index dimension in the first place.

While the concept of cultural dimensions in general remains valid, this study shows that linking some masculine or feminine values to cultural behaviours cannot be supported statistically. Our findings would tend to be comforted by the early work of Hofstede himself, acknowledging a poor correlation of the MAS with other three dimensions (Hofstede, 1980). He later changed the questions in his questionnaire but it appears today as only bending the facts to fit the model. One way to keep the original model unchanged and yet to accommodate with criticism was to add new dimensions. For instance, following documented criticism by fellow researchers (Fang, 2003), Hofstede subsequently replaced his fifth "Confucius dimension" introduced after his original four dimensions with a more neutral "Long Term Orientation" (Minkov, 2007).

If the authors approve the usefulness of the cultural dimension of Gender Equalitarianism as presented by in the GLOBE Project, and do not deny differences between individuals that could characterise so called "feminine/masculine" inclinations towards assertiveness, caring and the like, they strongly reject the hypothesis that such characteristics can be applied as a dimension to analyse dominant "patterns of socialization in nations" as Hofstede claimed (1994).

As a conclusion, the authors advise academics and practitioners of cross-cultural management to discard the MAS index in their work and instead to use other instruments such as Welzel's Emancipative Values Index (2013), or the Gender Equalitarianism of the Globe Study which focuses exclusively on gender, an unambiguous cultural dimension. 


\section{Appendices}

\section{MAS Index definitions throughout editions}

In his 1984 edition of Culture's Consequences, Hofstede introduces the index as such:

"The predominant socialization pattern is for men to be more assertive and for women to be more nurturing. In organizations, there is a relationship between the perceived goals of the organization and the career possibilities for men; hospitals have more "feminine" goals." (p. 176)

In the 1991 edition of Cultures and Organizations, Hofstede defines the two ends of the index as such:

"Masculinity pertains to societies in which social genders roles are clearly distinct (i.e., men are supposed to be assertive, tough, and focused on material success whereas women are supposed to be more modest, tender, and concerned with the quality of life); femininity pertains to societies in which social gender roles overlap (i.e. both men and women are supposed to be modest, tender, and concerned with the quality of life)." (p. 82-83)

The definition in the 2001 edition is a lot more careful, trying to prevent the author from being criticised for his own gender stereotypes:

"The label chosen needs some explanation. The English language (unlike, for example, Dutch) distinguishes between male/female and masculine/feminine. The first pair of words usually refers to what is biologically determined and I shall use these words in that sense. The latter pair of words usually refer to what, in a given environment, is deemed socially suitable for members of one gender rather than the other:

The words masculine and feminine do not refer in any simple way to fundamental traits of personality, but to the learned styles of interpersonal interactions which are deemed to be socially appropriate to specific social contexts, and which are imposed upon, and sustain and extend, the sexual dichotomy." 


\section{Data used in the study}

\section{Table 4 : MAS index and other data}

\begin{tabular}{|c|c|c|c|c|c|c|c|c|c|c|c|c|c|c|}
\hline Country & MAS & def & aid & gii & wmo & gpg & hdi & con & dch & dot & nod & rank & Fped & |Fted \\
\hline Sweden & 5,00 & 1,28 & 0,01 & 0,06 & 32,34 & 15,88 & 0,89 & 1,00 & 1,00 & 0,00 & 0,00 & 1,00 & 77,10 & 44,30 \\
\hline Norway & 8,00 & 1,58 & 0,02 & 0,07 & 31,33 & 15,48 & 0,94 & 1,00 & 1,00 & 0,00 & 0,00 & 2,00 & 75,00 & 45,50 \\
\hline Netherland: & 14,00 & 1,37 & 0,01 & 0,05 & 27,48 & 42,50 & 0,90 & 1,00 & 0,00 & 0,00 & 1,00 & 3,00 & 86,20 & 44,40 \\
\hline Denmark & 16,00 & 1,37 & 0,01 & 0,06 & 23,78 & 20,50 & 0,89 & 1,00 & 1,00 & 0,00 & 0,00 & 4,00 & & \\
\hline Slovenia & 19,00 & 1,41 & 0,00 & 0,08 & 35,38 & 7,05 & 0,86 & 1,00 & 1,00 & 0,00 & 0,00 & 5,00 & 97,20 & 41,10 \\
\hline Costa Rica & 21,00 & & & 0,35 & 30,42 & & 0,74 & 0,00 & 1,00 & 0,00 & 0,00 & 6,00 & 79,10 & \\
\hline Finland & 26,00 & 1,31 & 0,01 & 0,08 & 29,51 & 19,28 & 0,87 & 1,00 & 1,00 & 0,00 & 0,00 & 7,00 & 79,80 & 51,10 \\
\hline Chile & 28,00 & 2,27 & & 0,36 & 32,72 & & 0,80 & 0,00 & 1,00 & 0,00 & 0,00 & 8,00 & & \\
\hline Estonia & 30,00 & 1,89 & 0,00 & 0,16 & 36,23 & 31,42 & 0,82 & 1,00 & 0,00 & 0,00 & 1,00 & 9,00 & 91,10 & 48,90 \\
\hline Portugal & 31,00 & 1,96 & 0,00 & 0,11 & 31,18 & 13,25 & 0,81 & 1,00 & 1,00 & 0,00 & 0,00 & 10,00 & 80,10 & 44,40 \\
\hline Thailand & 34,00 & 1,41 & & 0,36 & 23,69 & & 0,70 & 0,00 & 0,00 & 1,00 & 0,00 & 11,00 & & \\
\hline Russian $\mathrm{Fe}$ & 36,00 & 3,75 & & 0,31 & 37,08 & 33,65 & 0,76 & 1,00 & 0,00 & 0,00 & 1,00 & 12,00 & 98,80 & 59,00 \\
\hline Guatemala & 37,00 & 0,46 & & 0,54 & & & 0,60 & 0,00 & 0,00 & 0,00 & 1,00 & 13,00 & & \\
\hline Suriname & 37,00 & 1,20 & & 0,47 & & & 0,70 & 0,00 & 0,00 & 0,00 & 1,00 & 14,00 & & \\
\hline Uruguay & 38,00 & 2,02 & & 0,37 & 40,27 & & 0,77 & 0,00 & 0,00 & 0,00 & 1,00 & 15,00 & & \\
\hline Korea (Sou & 39,00 & 2,52 & & & & & 0,87 & 1,00 & 0,00 & 0,00 & 1,00 & 16,00 & 78,40 & 35,00 \\
\hline Bulgaria & 40,00 & 2,04 & & 0.22 & 32,29 & 19,45 & 0,76 & 1,00 & 1,00 & 0,00 & 0,00 & 17,00 & & \\
\hline El Salvador & 40,00 & 1,05 & & 0,44 & 24,66 & & 0,65 & 1,00 & 1,00 & 0,00 & 0,00 & 18,00 & & \\
\hline Vietnam & 40,00 & 2,08 & & & & & 0,62 & 0,00 & 0,00 & 0,00 & 1,00 & 19,00 & & \\
\hline Peru & 42,00 & 1,36 & & 0,39 & 19,44 & & 0,71 & 1,00 & 1,00 & 0,00 & 0,00 & 20,00 & & \\
\hline Romania & 42,00 & 1,60 & & 0,33 & 29,39 & 11,87 & 0,77 & 1,00 & 1,00 & 0,00 & 0,00 & 21,00 & & \\
\hline Spain & 42,00 & 1,05 & 0,00 & 0,10 & 32,27 & 25,52 & 0,86 & 1,00 & 1,00 & 0,00 & 0,00 & 22,00 & 76,20 & 42,50 \\
\hline France & 43,00 & 2,34 & 0,01 & 0,08 & 38,51 & 17,75 & 0,87 & 1,00 & 1,00 & 0,00 & 0,00 & 23,00 & 82,10 & 37,90 \\
\hline Iran & 43,00 & 2,77 & & & 13,28 & & 0,71 & 1,00 & 0,00 & 1,00 & 0,00 & 24,00 & & \\
\hline Panama & 44,00 & 0,98 & & 0,50 & 48,08 & & 0,75 & 0,00 & 1,00 & 0,00 & 0,00 & 25,00 & & \\
\hline Turkey & 45,00 & 2,52 & 0,00 & 0,37 & 9,84 & & 0,72 & 1,00 & 0,00 & 1,00 & 0,00 & 26,00 & & \\
\hline Indonesia & 46,00 & 0,78 & & 0,49 & 22,10 & & 0,66 & 1,00 & 0,00 & 1,00 & 0,00 & 27,00 & 61,50 & 50,20 \\
\hline Israel & 47,00 & 7,19 & 0,00 & 0,14 & 32,12 & 36,46 & 0,88 & 1,00 & 0,00 & 1,00 & 0,00 & 28,00 & 85,30 & \\
\hline Malta & 47,00 & 0,68 & & 0,24 & 17,35 & 14,65 & 0,81 & 0,00 & 1,00 & 0,00 & 0,00 & 29,00 & & \\
\hline Singapore & 48,00 & 3,83 & & 0,10 & 31,44 & & 0,87 & 0,00 & 0,00 & 0,00 & 1,00 & 30,00 & & \\
\hline Brazil & 49,00 & 1,51 & & 0,45 & 36,08 & & 0,73 & 0,00 & 1,00 & 0,00 & 0,00 & 31,00 & 89,30 & 45,60 \\
\hline Luxembour & 50,00 & 0,59 & 0,01 & 0,15 & & 18,89 & 0,88 & 1,00 & 1,00 & 0,00 & 0,00 & 32,00 & 75,80 & 37,90 \\
\hline Malaysia & 50,00 & 1,94 & & 0,26 & 24,23 & & 0,76 & 0,00 & 0,00 & 1,00 & 0,00 & 33,00 & & \\
\hline Pakistan & 50,00 & 3,68 & & 0,57 & 2,97 & & 0,52 & 1,00 & 0,00 & 1,00 & 0,00 & 34,00 & & \\
\hline Canada & 52,00 & 1,16 & 0,00 & 0,12 & 35,99 & 27,16 & 0,89 & 1,00 & 0,00 & 0,00 & 1,00 & 35,00 & 74,40 & 49,40 \\
\hline Morocco & 53,00 & 3,45 & & 0,44 & 12,79 & & 0,59 & 1,00 & 0,00 & 1,00 & 0,00 & 36,00 & & \\
\hline Belgium & 54,00 & 1,10 & 0,01 & 0,10 & 32,68 & 24,01 & 0,88 & 1,00 & 1,00 & 0,00 & 0,00 & 37,00 & 81,80 & 48,60 \\
\hline Bangladest & 55,00 & 1,15 & & 0,52 & 23,39 & & 0,52 & 1,00 & 0,00 & 1,00 & 0,00 & 38,00 & & \\
\hline Argentina & 56,00 & 0,75 & & 0,38 & 23,12 & & 0,79 & 1,00 & 1,00 & 0,00 & 0,00 & 39,00 & & \\
\hline India & 56,00 & 2,62 & & 0,61 & & & 0,55 & 1,00 & 0,00 & 1,00 & 0,00 & 40,00 & 49,50 & \\
\hline Czech Rep & 57,00 & 1,40 & 0,00 & 0,12 & 28,06 & 25,28 & 0,85 & 1,00 & 0,00 & 0,00 & 1,00 & 41,00 & 94,00 & 40,10 \\
\hline Greece & 57,00 & 2,69 & 0,00 & 0,14 & 28,33 & 23,80 & 0,85 & 1,00 & 1,00 & 0,00 & 0,00 & 42,00 & 70,00 & \\
\hline New Zealar & 58,00 & 1,04 & 0,00 & 0,16 & 39,95 & & 0,90 & 1,00 & 0,00 & 0,00 & 1,00 & 43,00 & 83,80 & 48,80 \\
\hline Trinidad & 58,00 & 0,55 & & & 43,48 & & 0,75 & 0,00 & 0,00 & 0,00 & 1,00 & 44,00 & & \\
\hline Australia & 61,00 & 1,86 & 0,00 & 0,12 & 36,72 & & 0,92 & 1,00 & 0,00 & 0,00 & 1,00 & 45,00 & & \\
\hline United Stat & 62,00 & 4,10 & 0,00 & 0,26 & 42,67 & 41,20 & 0,90 & 1,00 & 1,00 & 0,00 & 0,00 & 46,00 & 87,10 & 49,10 \\
\hline Ecuador & 63,00 & 2,63 & & 0,44 & 27,72 & & 0,70 & 0,00 & 1,00 & 0,00 & 0,00 & 47,00 & & \\
\hline South Afric: & 63,00 & 1,28 & & 0,46 & 29,97 & & 0,64 & 1,00 & 0,00 & 0,00 & 1,00 & 48,00 & & \\
\hline Colombia & 64,00 & 3,43 & & 0,46 & & & 0,70 & 1,00 & 1,00 & 0,00 & 0,00 & 49,00 & 76,90 & 61,00 \\
\hline Philippines & 64,00 & 1,30 & & 0,42 & 54,82 & & 0,65 & 0,00 & 1,00 & 0,00 & 0,00 & 50,00 & & \\
\hline Poland & 64,00 & 1,86 & 0,00 & 0,14 & 36,13 & 17,10 & 0,82 & 1,00 & 1,00 & 0,00 & 0,00 & 51,00 & 85,40 & 44,40 \\
\hline China & 66,00 & 2,08 & & 0,21 & 16,75 & & 0,68 & 0,00 & 0,00 & 0,00 & 1,00 & 52,00 & & 25,21 \\
\hline Germany & 66,00 & 1,32 & 0,00 & 0,08 & 37,81 & 21,90 & 0,90 & 1,00 & 0,00 & 0,00 & 1,00 & 53,00 & 86,80 & 38,20 \\
\hline United King & 66,00 & 2,32 & 0,01 & 0,21 & 34,60 & 25,90 & 0,89 & 1,00 & 0,00 & 0,00 & 1,00 & 54,00 & 84,50 & 44,40 \\
\hline Ireland & 68,00 & 0,55 & 0,00 & 0,12 & 31,88 & 21,10 & 0,89 & 1,00 & 1,00 & 0,00 & 0,00 & 55,00 & 87,00 & 44,00 \\
\hline Jamaica & 68,00 & 0,76 & & 0,46 & & & 0,71 & 0,00 & 1,00 & 0,00 & 0,00 & 56,00 & & \\
\hline Mexico & 69,00 & 0,50 & & 0,38 & 30,72 & & 0,74 & 0,00 & 1,00 & 0,00 & 0,00 & 57,00 & 67,70 & \\
\hline Italy & 70,00 & 1,72 & 0,00 & 0,09 & 33,24 & 26,27 & 0,86 & 1,00 & 1,00 & 0,00 & 0,00 & 58,00 & 95,90 & 37,30 \\
\hline Switzerlanc & 70,00 & 0,78 & 0,01 & 0,06 & 30,00 & 20,06 & 0,91 & 1,00 & 0,00 & 0,00 & 1,00 & 59,00 & 81,80 & 34,30 \\
\hline Venezuela & 73,00 & 1,23 & & & & & 0,74 & 0,00 & 1,00 & 0,00 & 0,00 & 60,00 & & \\
\hline Austria & 79,00 & 0,84 & 0,00 & 0,10 & 28,30 & 35,06 & 0,87 & 1,00 & 1,00 & 0,00 & 0,00 & 61,00 & 91,60 & 42,70 \\
\hline Hungary & 88,00 & 1,22 & 0,00 & 0,26 & 36,39 & 19,07 & 0,81 & 1,00 & 0,00 & 0,00 & 1,00 & 62,00 & 96,80 & 42,10 \\
\hline Japan & 95,00 & 0,99 & 0,00 & 0,13 & & & 0,88 & 1,00 & 0,00 & 1,00 & 0,00 & 63,00 & 64,80 & 26,81 \\
\hline Slovak Rep & 110,00 & 1,43 & 0,00 & 0,17 & & & 0,82 & 1,00 & 1,00 & 0,00 & 0,00 & 64,00 & 89,70 & 45,40 \\
\hline
\end{tabular}




\section{References}

Adorno, T. (1950), The authoritarian personality. New York: Harper Row

Ahlstrom, D., Bruton, G. (2009). International Management: Strategy and Culture in the Emerging World, Cengage Learning.

Barro, R.J. and Sala-i-Martin, X. (2004). Economic Growth - Second Edition, MIT Press, Cambridge, MA.

Baskerville, R. (2003). "Hofstede never studied culture ». Accounting, Organizations and Society 28 (2003) 1-14. https://doi.org/10.1016/S0361-3682(01)00048-4

Benedict, Ruth, (1946). The Chrysanthemum and the Sword: Patterns of Japanese Culture, Houghton Mifflin

Bond, M. H. (2002). "Reclaiming the Individual From Hofstede's Ecological Analysis- A 20-Year Odyssey: Comment on Oyserman et al. (2002)." Psychological Bulletin 128(1): 73-77. https://doi.org/10.1037/0033-2909.128.1.73

Browaeys, M.-J, (2008), Understanding Cross-Cultural Management, Pearson

Chevrier, S., 2003, Le Management Interculturel, Presses Universitaires de France

Cyert, R. M., \& March, J. G. (1963). A behavioral theory of the firm. Englewood Cliffs, NJ, 2.

Dorfman, P. W. and J. P. Howell (1988). "Dimensions of National Culture and Effective Leadership Patterns: Hofstede revisited." Advances in International Comparative Management 3: 127-150.

Dumetz, J. (Ed.). (2012). Cross-cultural Management Textbook: Lessons from the world leading experts. CreateSpace, Charleston, SC

Emrich, C., Denmark, F. and den Hartog, D., (2004). Cross-Cultural differences in Gender Egalitarianism: implications for societies, organizations and leaders. In P.J..Hanges M. Javidan R.J. House \& GLOBE.associates V. Gupta (Eds.), Cultures, Leadership and Organizations: a 62 nation GLOBE study (Vol. 1). Thousand Oaks, CA: Sage.

Fang, T., (2003), A Critique of Hofstede's Fifth National Culture Dimension, International Journal of Cross Cultural Management, December 2003; vol. 3, 3: pp. 347-368. https://doi.org/10.1177/1470595803003003006

Fayol, H. (1918), Administration industrielle et générale, Dunod

Gerhart, B. and Fang, M. (2005), National Culture and Human Resource Management: Assumptions and Evidence, International Journal of Human Resource Management, 16.6, 971-986. https://doi.org/10.1080/09585190500120772

Hall, Edward T., (1966), The Hidden Dimension, Anchor Books

Hampden-Turner C, Trompenaars, F. (1997) « Response the Geert Hofstede », International Journal of 
Intercultural Relations, Volume 21, No. 1, Pages 149-159. https://doi.org/10.1016/S01471767(96)00042-9

Hofstede G., (2001), Cultural Consequences : Comparing values, behaviors, institutions and organizations across nations, Sage Publ.

Hofstede, G. (1980), Culture's consequences: international differences in work-related values, Beverly Hills, CA: Sage Publications.

Hofstede, G. (1984), Culture's consequences: international differences in work-related values, Sage Publications.

Hofstede, G. (1991), Cultures and Organizations : Software of the Mind. Intercultural cooperation and its importance for survival, HarperCollins Publ.

Hofstede, G. (1997). The Archimedes effect. Working at the interface of cultures: 18 lives in social science. M. H. Bond. London, Routledge: 47-61.

Hofstede, G. (2002). "Dimensions do not exist: A reply to Brendan McSweeney " Human Relations, 55 (II), P. 2-7. https://doi.org/10.1177/0018726702055011921

Hofstede, G., (1996), «Riding the waves of commerce: A test of Trompenaars' "model” of national culture differences. International Journal of Intercultural Relations, Volume 20, Issue 2, Pages 189-198. https://doi.org/10.1016/0147-1767(96)00003-X

Hofstede, G., \& Vunderink, M. (1994). A case study in masculinity/femininity differences: American students in the Netherlands vs. local students. In Journeys into cross-cultural psychology: Selected papers from the eleventh International Conference of the International Association for Cross-Cultural Psychology held in Liege, Belgium (pp. 329-347).

Holden, N. (2001), Cross-cultural Management: A Knowledge Management Perspective, Financal Times Management; 1 ed.

Hoppe, Michael H. (1998), Validating the masculinity/femininity dimension on elites from 19 countries. In Hofstede, Geert (Ed), (1998). Masculinity and femininity: The taboo dimension of national cultures. Cross-cultural psychology series, Vol. 3., (pp. 29-43). Thousand Oaks, CA, US: Sage Publications, Inc, xviii, $238 \mathrm{pp}$.

House, Robert J.; et al., (2004), Culture, leadership, and organizations: the GLOBE study of 62 societies, SAGE

Jones, M., (2007) « Hofstede - Culturally questionable?», Oxford Business \& Economics Conference. Oxford, UK

Kluckhohn, F., and Strodtbeck, F. (1961). Variations in Value Orientations. Evanston, IL: Row, Peterson.

Kotha, Suresh and Steensma, H. Kevin and Rothaermel, Frank T. (2006), International Market Entry by U.S. Internet Firms: An Empirical Analysis of Country Risk, National Culture, and Market Size (2006). 
Journal of Management, Vol. 32, Issue 1, p. 56-82

McClelland, D. (1961), The Achieving Society, Van Nostrand. https://doi.org/10.1037/14359-000

McSweeney, B. (2002). "The essentials of scholarship: A reply to Geert Hofstede " Human Relations, 2002, 55 (II), p. 1363-1372. https://doi.org/10.1177/00187267025511005

McSweeney, B. (2002). Hofstede's Model of National Cultural Differences and their Consequences: A Triumph of Faith - a Failure of Analysis ,Human Relations, 2002; vol. 55, 1: pp. 89-118. https://doi.org/10.1177/0018726702551004

McSweeney, B., Brown, D., \& lliopoulou, S. (2016). Claiming too much, delivering too little: testing some of Hofstede's generalisations. The Irish Journal of Management, 35(1), 34-57. https://doi.org/10.1515/ijm-2016-0003

Mead, R., 2009, International Management, Wiley-Blackwell; 4th edition

Merritt, A. (2000). Culture in the cockpit do Hofstede's dimensions replicate?. Journal of cross-cultural psychology, 31(3), 283-301. https://doi.org/10.1177/0022022100031003001

Minkov, M. and Hofstede, G. (2010). Hofstede's fifth dimension: new evidence from the World Values Survey. Journal of Cross-Cultural Psychology, 43(1), pp.3-14.

Minkov, M. (2007). What makes us different and similar: A new interpretation of the World Values Survey and other cross-cultural data. Sofia, Bulgaria: Klasika y Stil Publishing House

Minkov. M. (2017), A revision of Hofstede's model of national culture: Old evidence and new data from 56 countries. Cross-Cultural and Strategic Management.

Morschett, D. (2010), Strategic International Management, 2nd, ed. Gabler

Nutt, P. (1988). The effects of culture on decision making, Omega, Volume 16, Issue 6, Pages 553-567. https://doi.org/10.1016/0305-0483(88)90029-1

P. Myasoedov. S., (2012) Fundamentals of cross-cultural management. How to do business with other countries and cultures: Textbook - 2-e ed. Publisher: Delo

Pheng, L.S. and Yuquan, S. (2002): An Exploratory Study of Hoftede's cross-cultural dimensions in $\begin{array}{lllll}\text { construction } \quad \text { projects. } & \text { Management }\end{array}$ https://doi.org/10.1108/00251740210423036

Schwartz, S. H. (1999), "A Theory of Cultural Values and Some Implications for Work ", Applied Psychology 48(1): 23-47. https://doi.org/10.1111/j.1464-0597.1999.tb00047.x

Shao, R, Rupp, D., Skarlicky, D., Jones, K.(2011) Employee Justice Across Cultures: A Meta-Analytic Review, Journal of Management

Smith, P. B., Dugan, S., \& Trompenaars, F. (1996). National culture and the values of organizational employees-a dimensional analysis across 43 nations, Journal of Cross-Cultural Psychology, 27, 
231-264.

Søndergaard, M. (1994). "Hofstede's consequences: A study of reviews, citations and replications." Organization Studies 15(3): 447. https://doi.org/10.1177/017084069401500307

Spector, P., Cooper, CC, Sparks, K, (2001), An International Study of the Psychometric Properties of the Hofstede Values Survey Module 1994: A Comparison of Individual and Country/Province Level Results, Applied Psychology, vol 50 (2), 269 \pm 281

Taylor, F. (1911), The Principles of Scientific Management, Harper \& Brothers

Terman, L., Miles, C., (1936), Sex and Personality: Studies in Masculinity and Feminity, McGraw-Hill. https://doi.org/10.1037/13514-000

Trompenaars, F. (1993), Riding the waves of culture: understanding cultural diversity in global business. 1st ed. Chicago, IL: Irwin Professional Publishing.

Yeh, R. (1988), On Hofstede's Treatment of Chinese and Japanese Values, Asia Pacific Journal of Management, Vol 6. https://doi.org/10.1007/BF01732256

Welzel, C. (2013). Freedom rising. Cambridge University Press. https://doi.org/10.1017/CBO9781139540919

\section{Data sources:}

The World Bank, "Military expenditure (\% of GDP) available at: http://data.worldbank.org/indicator/MS.MIL.XPND.GD.ZS (Accessed 1 Oct 2017).

OECD, "Total net ODA disbursements", available at: http://www.oecd.org/dac/stats/idsonline.htm (Accessed 1 Oct 2017)

ECD, "Education at a Glance 2015", available at: http://www.oecd.org/edu/education-at-a-glance2015.htm (Accessed 1 Oct 2017)

UNDP, “Gender Inequality Index” , available at: http://hdr.undp.org/en/content/gender-inequality-index-gii (Accessed 1 Oct 2017).

UNECE (United Nations Economic Commission for Europe). "Gender statistics: Gender pay gap" http://w3.unece.org/pxweb/Dialog/varval.asp?ma=017 GE GPG2 r\&path=../database/STAT/30GE/03-WorkAndeconomy/\&lang=1 (Accessed 1 Oct 2017).

UNECE (United Nations Economic Commission for Europe). "Gender statistics: Employment by Occupation and Sex". http://w3.unece.org/pxweb/Dialog/varval.asp?ma=004 GEWEEmpISCO88SPN r\&path=../databas e/STAT/30-GE/03-WorkAndeconomy/\&lang=1 (Accessed 1 Oct 2017).

UNDP, "Human Development Index (HDI)", available at http://hdr.undp.org/en/content/human- 
development-index-hdi (Accessed 1 Oct 2017).

Uppsala Conflict Data Program, „UCDP/PRIO Armed Conflict Dataset“ http://www.pcr.uu.se/research/ucdp/datasets/ucdp_prio_armed_conflict_dataset/ (Accessed 1 Oct 2017).

CIA World Factbook, "Religions" https://www.cia.gov/library/publications/the-worldfactbook/fields/2122.html (Accessed 1 Oct 2017). 